\title{
A New Direction of Culture Education in English Education in Korea"
}

\author{
Hoyeol Ryu \\ (Hankyong National University)
}

\section{Introduction}

The understanding of the interlocutor's cultural norms has been regarded as having critical importance in language teaching and learning. This is particularly true in foreign language teaching and learning, because students are required to communicate with those whose cultural backgrounds are different from theirs. When students lack the understanding of what cultural norms govern their communication partners' behaviors, it seems very difficult to expect them to function properly in a given communication situation. Therefore, culture should be eagerly integrated into foreign language curricula and taught to students to improve their communication abilities.

English has been used as lingua franca since the end of the Second World War. There are many elements which contribute to this phenomenon. The growing influence of the United States in economics and politics in the global community has surely contributed to the emergence of English as the world language. The dominance of the United States and other English-speaking countries

1) 본 연구누ㄴㅡㅡ 한경대학교 고내 학술연 证지원비의 지 원을 받아 수행되었윾. in the community made communication with the native speakers the sole purpose of studying English. However, with the rapid development of transportation and telecommunication technologies, people have come to have more opportunities to travel abroad and communicate with foreigners. In such a situation, English, which is already readily available to people around the world, has become a convenient communication tool between those with different linguistic background. Therefore, English should be seen as a tool for international communication, including that with the native speakers.

As English has become a widely-used tool for international communication, we need to reconsider the cultural content in Korean English textbooks. The growth of Korean economy gives its people more opportunities to communicate with those whose native languages are other than English. For example, while Korean economy heavily relied upon the aid from and trade with the United States in the past, its economic development has greatly reduced its dependence on the United States. Instead, China, Japan, European countries, and many other countries around the world have become major trade 
partners with Korea. The emergence of English as the global language as well as the growth of Korean economy make the exclusive presentation of English-speaking countries' culture in Korean English textbooks a legitimate question to answer.

This paper begins with the review of the studies which gives a full account for the integration of culture in foreign language teaching and learning. The second part discusses the emergence of English as a language for international communication and the use of English for international communication in Korean context. Then, the analysis of Korean high school English textbooks is conducted as an attempt to draw principles required in teaching English as a language for international communication. The summary and implications of the present study is given at the concluding part of the paper.

\section{Culture and Foreign Language Learning}

The integration of culture into the curriculum carries special importance in foreign language teaching and learning. The purpose of foreign language education is to help students build abilities to communicate with those who do not share the same linguistic background with them. Those with the different linguistic background usually do have the different cultural frame of reference, and this difference poses a considerable amount of difficulties in communication. Therefore, foreign language teachers should eagerly integrate cultural content into the language curricula and help their students build communicative competence necessary in a given communication situation.

\section{Concept of culture}

It is of prime importance for foreign language teachers to understand what the term of culture implies in relation to teaching language. The meaning of culture is very comprehensive, so it is not easy for the teachers to determine what cultural content to include in the curriculum. In this sense, the knowledge of its concept helps them improve the understanding of the relationship between culture and language, as well as determine the appropriate content to teaching foreign language. Moreover, this understanding, in turn, enables them to practice the instruction in a proper manner.

Culture is such an elusive term that it is very difficult to define it in a clear fashion. Eventually, the term has multi-facets, so we need to examine it from many different perspectives. Kramsch (1993) mentioned that culture was a multidisciplinary term and ran over the disciplines of anthropology, sociology, and semiology. Seelye (1984) also discussed the difficulty of defining the term and found that there were approximately 300 definitions of culture in Kroeber and Kluckhohn's study (1954). Further, Moran (2001) maintained that culture could be discussed from seven different perspectives which view it as civilization, communication, general concept, intercultural communication, groups or communities interact, dynamic construction between and among people, and evolutionary psychology. Therefore, instead of trying to grasp a clear definition of culture, many studies suggests that we reach a better 
understanding of it by studying its multiple meanings from different perspectives.

In the study of asking EFL teachers in Mexico to draw on metaphorical images of culture, the teachers could bring out five different images of culture (Ryan, 1996). One image a teacher could come up with was a complex ball of yarn which signified the sum total of his experiences. This vicw of culture clearly indicates that culture is a personal matter. The second image was "a big machine with a motor and screws, all a part of the whole," which saw culture as a global whole and stressed its structural charac teristics. The third image was overlapping circles, suggesting that, when people are together and doing something, they could be regarded as a cultural group. The fourth image was a bubble which suggested the perpetuation of political aspects of culture over individuals. The last teacher depicted culture as a mosaic. In his explanation, the culture of a country was described as a multiplicity of cultures in perpetual change, cmphasizing the changing quality of culture. Overall, these five metaphors well highlighted the fact that culture could be discussed in term of group vs. individual, static vs. changing, and microscopic vs. macroscopic perspectives.

In addition to different perspectives on culture, many attempts have becn made to identify the basic elements which constitute culture. First of all, Hammers (1985) suggested that the following four condition of culture be explored in a forcign language curriculum. The first condition is the physical conditions which refer to geography, climate, and things in one's life. The sccond condition is social environment that includes family, friends, and all those other people in the past and present who make a person feel onesclf in his or her life. The third condition is temporal orientation which comprises the history of onc's culture and how one's life relates to that history. Finally, the unique genetic heritage refers to onc's inherited mental and physical features which commonly appear to many of a cultural group. Hammer's idea of culture strongly suggests a hermencutical view that it should be interpreted at an individual level and that every cultural phenomenon be shaped differently depending on one's interpretation.

Moran (2001) added another picture to the concept. He defined culture as "the evolving way of life of a group of persons, consisting of a shared set of practices associated with a shared set products, based upon a shared set of perspectives on the world, and yet within specific social contexts." (p. 21) Then, he listed five elements of culture. The first element is products which represent all artifacts produced or adopted by the members of a cultural group. The second one is practices which means the actions and interactions that members of a cortain cultural group carry out. It includes communication means and actions associated with the use of the products. The third one is perspectives which include perceptions, beliefs, values, and attitudes that underlie the products and practices. The fourth one is communities which represent the specific social contexts, circumstances, and groups where members of a certain group carry out cultural practices. And the last one is persons which refer to individual members of a specific culture and its communities in unique ways. Moran added that all of the five 
clements interacted with one another and shaped the whole picture of culture.

Culture was defined in terms of five orientations people assumed in relation to the nature of humankind (Jourdain, 1998). In the study of introducing a student centered approach to teaching culture, Jourdain introduced Kluckhohn and Strodtbeck's study (1961) to explain the elements necessary to reach a decper understanding of culture. which can be discussed in terms of five different orientations which include human nature, man nature relationship, time, activity, and relation to other people. Morcover, Jourdain suggested that students better understand the underlying differences between two cultures by reflecting on the answers to the five questions.

Flowelling (1991) explained two contrasting concepts of culute, which may have direct implications to teaching culture in forcing language curricula. The first type is the "capital C culture." The capital C culture refers to the civilization associated with the language being studied. It concerns with the study of the art, literature, philosophy, tochnology, and other aspects of people associated with the language. In contrast, the small c culture refers to a people's customs, manners, values, and beliefs. The concept of the small $c$ culture is particularly important in forcign language tcaching and lcarning in that its understanding gives the better understanding of the people with whom one is trying to communicate. Heusinkveld (1985) made a similar distinction between two types of culture: Deep culture vs. surface culture. While decp culture is one's cultural attitudes, beliefs, and underlying values, surface culture can be defined as the external manifestation of the underlying attitudes and values. These distinctions clearly indicate what aspect of culture should be emphasized in forcign language classrooms.

The reviewed studies suggest two important points in our attempt to understand the concept. The first one is that culture is interpreted differently in each individual. One's point of view clearly makes him or her stress a certain aspect of culture over the others, so many different cultural concepts can be generated. The other point is that many attempts to define the concept emphasize the importance of the underlying rules which govern the cultural behaviors specific to a particular group. The proper understanding of the concept can greatly improve our tcaching practices by cnabling us to correctly determine what and how to tcach forcign culture.

\section{Culture in Foreign Language Learning}

Many studies, for example, those of Secyle (1981) and Moran (2001), point out that language and culture are inscparable in forcign language learning. Cortazzi and Jin (1998) stressed the importance of culture in language learning in the following manner: "Communication in real situations is never out of context, and because culture is a part of most contexts, communication is rarcly culture free." (p. 197). When we consider the integration of culture in foreign language lcarning, we should be able to provide appropriate answers to the following questions:

1. What is the purpose of teaching culture in forcign language classrooms? 
2. What cultural clements should be stressed in language teaching?

3. How should culture be taught in language classrooms?

Answers to those questions are believed to guide the teachers throughout the whole instructional process. $\Lambda$ s discussed carlicr, the answers should be based on the proper understanding of the concept of culture. Unless culture is taught with the understanding, tcaching culture is more likely to fail in developing students' cultural competence necessary to communicate with those from the different cultural background. The first question is about the purpose of teaching culture in a forcign language classroom. Kramsch (1998) contended that the purpose of cultural learning in a forcign language classroom was to help student become an intercultural speaker who possess the abilities "to help learners analyse, reflect. upon, and interpret forcign cultural pheno mena when using the language in contact with forcign nationals." (pp. 2728 ) The definition of an intercultural speaker clcarly indicates the goal as well as the legitimacy of culture learning in forcign language curricula. He suggested that students should be asked not only to properly understand forcign culture, but also to apply the understanding to communication with foreign speakers. Lantolf (1999) defined culture learning as the development of conceptual thinking. He insisted that, to some extent, it should be feasible to cultivate intercultural mind which is a result of restructuring conceptual organizations. In this vein, it secms clear that the goal of the culture learning does not lie in mere memorization of cultural facts, but in the development of the cognitive abilities to interpret new cultural phenomena from the learner's own perspectives and to appropriately use the new information for communicative purpose.

Morcover, students are required to develop the sense to appreciate cultural similarities and differences between their own and the target culture. Heusinkveld (1985) maintained in her study of tcaching Hispanic culture to American students that the understanding of the target culture comes from the identification of the students' own culture. She further stated that, through culture learning, students are expected to answer the following four questions:

1. Where do I come from?

2. What sets of my culture are apart from others?

3. How do people from other countries view my culture?

1. What different attitudes, values, and habits might I find in another culture, specifically Hispanic culturc? (p. 324)

The first two questions stress the importance of a student's identity as a member of his her own culture. It can be assumed that, only after do students have the sound under standing of their own culture, they are ready to appreciate forcign culture. Mantle Bromlcy (1992) emphasized the importance of the understanding of one's own culture before his or her lcarning of forcign culture as follows:

All learners' interpretations of cultural expression will nocessarily depend to a great degree on their previous experience. Without acknowledging this experience, the learner 
will find it much more difficult to organize the now information in a meaningful way ( $p$. 120 ).

Robinson (1988) also stressed that forcign culture learning can be facilitated by introducing the comparison of students' own culture with the target culture on familiar content first. Then, they can gradually move to culturally unfamiliar topics. It secms that the understanding of onc's own culture should be considered to be of significant importance in that it teaches students that their bchaviors are culturally conditioned, as well as it plays the role of a facilitator in studying unfamiliar target culture. The answer to the second question can be sought after by considering the first question. That is, if we can clarify the goal of culture cducation in forcign language curricula, it eventually guides us to identify the cultural clements that need to be presented in foreign language classrooms. The previous part supports the point that the goal of culture cducation should be developing students' cognitive ability to appreciate and understand the target culture. The distinction between the capital C culture and the small c culture is worth noting in determining the appro priate content in the curriculum. Hammers (1985) also noted two levels of culture. The unique outlook of the target culture on life and history helps students understand the people with whom they are trying to communicate to a certain extent. However, in onc's attempt to communicate with a person from the target culture, it is important to go beyond this level of culture. In other words, if we make an attempt to understand an individual from the target culture, we noed to understand the decper level of culture which underlies his or her thoughts, values, and bchaviors. Hammers suggested that, instead of trying to reach a direct understanding of individuals from the target culture, we should understand cultural conditions which shape their personalities and traits that make them unique to others. In forcign language learning context, the learners need to reach a decper level of cultural understanding which enables them to draw correct interpretations of the thoughts, values, bchaviors, and other things of an individual from the target culture to effoctively communicate with him or her in a given communication situation.

For the third question regarding the manner of presenting culture, it has been clearly suggested in the previous part that the mere presentation of cultural facts be not enough to achieve the goal of culture education, which enables students to reach a decper level of cultural understanding. In his explanation of the National Core French Study of Canada program, LcBlanc (1990) recommended that culture education be started from a smaller community level to a larger one. In the case of French culture education in Canada, the order of the instruction should be local, regional and provincial, Qucbec, North Amcrica, and finally France and other French Speaking countries. This way of presenting culture implies an important point in relation to presenting forcign culture. That is, the teaching should be started from culture which can be readily accessible and casily experienced by students, and move to the more remote and bigger units which is clusive and complicated to understand.

Another point to consider in teaching 
forcign culture is the development of students' cultural awareness. As students learn forcign culture, they are regarded as going through four stages of cultural awareness (Jourdain, 1998). Therefore, when the teacher plans the instruction, he or she should integrate the development level of his or her students' cultural awareness. In the beginning stage of cultural awareness, students cannot look at the target culture with an open and accepting attitude, so their understanding of the target culture is limited to its stereotypes. As they make a progress in the understanding of the culture, students can notice the significant and subtle differences between their own and the target culture. However, they still cannot look at the culture with an open and positive attitude. In the third phase of cultural awareness, they begin to look at the culture with a positive attitude. The final stage represents full cultural assimilation, which is often the result of lengthy cultural immersion. Jourdain pointed out that it is practically impossible to reach the final stage of cultural awareness through instructional practices in the classroom. The optimal goal of forcign culture instruction should be reaching the third stage and cach different tcaching strategies should be practiced based on the students' level of cultural awareness.

Mantle Bromley (1993) also pointed out the importance of a progressive, skill building manner of forcign culture instruction. The term, progressive, is specially important in that a student begins his or her cultural study with an awareness of his or her own cultural bchaviors and patterns and moves toward cxamining forcign bchaviors and patterns. After comparing and contrasting his or her own and forcign culture, the student may begin to develop the independent ability to make a sense out of unfamiliar cultural phenomena. One of the conditions for this progress in the development of cultural awareness is attitude readiness which can be developed through examining the beliefs about the target culture and learning how stereotypes are developed and maintained. Therefore, study of foreign culture should start from developing students' open, positive attitude toward the target culture. Then, they can move to the identification of their own as well as the target culture with decp cultural insights.

When the goal of culture education is in developing high levels of cultural awareness. simple presentation of cultural facts is far short of achicving the goal. Arries (1991) proposed that, instead of presenting mere cultural knowledge, students develop their understanding of the target culture through the anthropological process in which students are asked to conduct an anthropological study on the target culture. Rosenbusch (1992) also introduced a culture teaching model for clementary school students, in which students focused on a specific aspect of forcign culture and indirectly experienced the target language. It can be suggested that, if we want our students to develop a high level of cultural understanding, mere presentation of cultural knowledge is not enough. Instead, the teacher give his or her students opportunities to be immersed in the target culture and to experience it as a process.

So far, three basic issues regerding the education of forcign culture have been discussed so far. The first issue is the goal of forcign culture cducation. This study 
maintains that the goal should be developing students' cognitive abilities to reach a deeper level of cultural understanding and apply the understanding to a communication situation with the person from the target culture. This study also points out that the deeper understanding comes from the understanding of one's own culture. The second issue is the content of foreign culture education. Instead of presenting the surface level of culture, this study proposes that the deeper level of culture should be taught in the classroom. The last issue is the manner of foreign culture education. This study contends that foreign culture education should be practiced in a progressive manner based on the level of students' acculturation. Further, it is suggested that students should be given opportunities to experience foreign culture as a process rather than mere cultural knowledge.

\section{Multicultural Education in English Classrooms}

As the US has played a leading role in the international communities, English has also emerged as a common language for international communication. This emergence of English for international communication means that not only has it been used for communication between the native and non-native speakers, but also between the non-native speakers. The common use of English among the non-native speakers bears an important point in relation to this study. That is, as English is widely used by the non-native speakers, it is of prime importance to integrate foreign culture other than that of English-speaking countries in the English curricula, to help our students better prepared for communicating with those whose culture background is other than that of English-speaking countries.

\section{English as a Language for International Communication}

English has undoubtedly become the most common language for international communication since the end of World War Two. Graddol (1997) defined this dominance of English in international communication as the outcome of the British colonial expansion and the recent leading role of the US in international communities. This wide use of English can be evidenced in the language use of international organizations. According to Crystal (1997), 85 percent of international organizations use English as one of their working languages, opposed to 49 percent of French and fewer than 10 percent of Arabic, Spanish, or German. It seems that 49 percent use of French in the organizations, however, is somehow misleading. Since the end of World War Two, the power of French has been clearly in rapid decline, and its value in international communication can be found only in the political gesture of resistance to the hegemony of English. As a matter of fact, it seems clear that English enjoys incomparable power in the communication and is widely used in the communication between the non-native speakers.

Another evidence of the widespread use of English for international communication can be found in the expansion of Englishspeaking population worldwide. Crystal (1997) reported that there are three circles in the 
use of English. The first circle is the inner circle which refer to such countries as US $\Lambda$, UK, Ireland, Canada, Australia, and Now Zcaland where English has been traditionally used for the prime language in the societies. Crystal estimated that the total number of the inner circle population was approximately 320 to 380 millions. The next circle is the outer or extended circle where English becomes part of a country's chicf institutions as well as an important second language in a multicultural setting. This circle includes India, Singapore, Malawi, and other countries. The total number of the outer circle populations was estimated approximately 150 to 300 millions. The last circle is the expanding circle where the importance of English as an international language is well recognized, but there is no history of colonization by the member of the inner circle. In the expanding circle countries, although the importance of English as an international language is well recognized by their governments and people, English is not used for official purposes and taught as a forcign language. The expanding circle includes such countries as Japan. China, and other countries all over the world. The total number of the expanding circle population was estimated approximately 100 million to onc billion.

The maximum number of those who either speak English as a first or second language or study English as a forcign language amounts to approximatcly 1.7 billion. This number cquals approximately 30 pereent of the total population of the world. However, the figure secms very conservative, in that, as the world has been repidly globalized, the importance of English has been well recognized and put into educational practices worldwide. With respect to this trend of the expansion of English, the important point worth noting is the expansion of the expanding circle. In recent years, when people need to communicate with those whose linguistic background differs from theirs, instead of studying the conversation partners' native languages, more and more poople tend to rely on English. In many cases, English seems to be a sole forcign language one has studied and possess a decent control of. That is, in many cases, English is the language for communicating with not only the native speakers but also those who have different linguistic background from ours.

\section{English in Korean Context}

Lcarning English always carrics a special meaning to Korcans. The reason bchind this valuing of English in Korcan socicty may be the strong political, economic influence of the US over Korea since the end of the Second World War. However, although the LS is still an important country to Koreans, their reliance on the US has decreased with Korcan political, cconomic growth in the international community. One example that shows one country's dependence on another country may the exchange of people between the two countries. In this light, the recent decrease in the percentage of Korcan travelers to the $\mathrm{LS}$ and other English spcaking countrics clcarly shows that Korcan political, economic interests are diversificd, rather than relying on a few countries. According to the data by the Korean Statistical Office, among approximately $3 . \overline{5}$ 
million Korcan travelers abroad, 19.7 percent visited the LS in 1994. This figure dropped rather dramatically in 2001. Among 5.7 million Korcan travelers abroad, 13.1 percent visited the country in 2001. This trend equally applies to all of English speaking countries. In 1991, about 26.7 percent of Korcan travelers abroad visited English speaking countries, including the United States, the Lnited Kingdom, Canada, Australia, New Zealand, and Guam. However, the figure dropped to 21.6 percent in 2001 .

$\Lambda$ survey was conducted to investigate Korcan travelers' language use in forcign countries. 81 travelers participated in the survey by answering the five questions on the questionnaire, which is presented in the Appendix. The first question was about the travelers' visiting countries. The visiting countries included 17 countries and regions. 22 travelors said they would visit English speaking countries, including the US, UK, Australia, Canada, and New Zealand. 27 travelers visited the neighboring countries which refer to Japan, China, and Russia. And 35 travelers said they would visit distant and non English speaking countries, which were mostly south cast $\Lambda$ sian, Europcan, and central or south $\Lambda$ merican countrics.

Most of the travelers to the English speaking countries said they were capable of speak English and planned to use it in the visiting countrics. However, three respondents said they neither had any control of English nor planned to use any forcign language in the countries. It seemed that they would visit their family members and other acquaintances in the countries. One interesting point about the travelers to English spcaking countries was that two of them said they would speak
Japanese if they could communicate in Japanese. This could be explained in terms of their superior Japanese speaking ability to the English one. For the fourth question which asked the travelers' knowledge of culture and customs of the visiting countries, three respondents said they had little knowledge of the culture and customs of the visiting countries, 8 respondents said a little, 9 respondents said some but not enough, and 2 respondents said enough knowledge of the target culture and customs. For the last question which asked the reason for experiencing difficulties in the visiting countries, it was proven that the lack of cultural knowledge gave a considerable number of the travelers difficulties in traveling to the countries. That is, 9 out of 22 respondents said their difficulty in the traveling came from their lack of proper cultural knowledge to deal with the problems they might face.

For the travelers to the distant and non English spcaking countries, including south cast $\Lambda$ sian, European, $\Lambda$ frican, and Latin Amcrican countrics, English was proven to be a major communication instrument. Out of 35 travelers to those countries, only three travelers said that they knew the local languages and planned to use them when they would be in the countries. In contrast, 21 travelers answered that they had a fair control of English and planned to use it. In regards to their knowledge of the target culture, 11 travelers answered that they had only a little knowledge of it and 11 travelers reported that they knew some but cnough to travel without difficulties. Finally, 26 travelers answered that the difficulties they experienced in traveling to the countries 
mainly came from their limited ability to communicate and 9 travelers chose the lack of the cultural knowledge.

In contrast, the survey showed that most travelers who traveled to the neighboring countries like Japan, China, and Russia had a good control of the local languages and planned to use them in their traveling. Out of 27 travelers to Japan, China, Russia, 22 travelers answered that they had a fair control of the languages and 21 travelers planned to use them while they were traveling to the countries. Only three travelers responded that they could speak English fairly and planned to use it in the countries. 11 travelers answered that they knew a little about the target culture and 10 travelers answered that they know some but not cnough to travel without difficulty. For the last question concerning the cause of the problems in traveling to the countries, in contrast to the travelers to the distant non English spcaking countrics, a considerable number of the travelers, 11 out of 27 travelers, reported that their problems were caused by their insufficient knowledge of the target culture. 18 travelers answered that their limited linguistic ability caused the problem. The Table 1, summarizes the overall result of the survey.

Although the survey itsclf has little scientific value, due to its limited sample size, the result shows some pictures of Korean forcign travelers' language use and the cause of their problems in traveling abroad. Among the travelers to non English spcaking coun tries, if we exclude those who answered that they had no communication tools, 27 out of 51 travelers answered that they planned to use English other than the local languages of
Table 1. The Result of the Survey of Language Use in Foreign Countries

\begin{tabular}{|c|c|c|c|c|}
\hline & $\begin{array}{l}\text { language } \\
\text { you can } \\
\text { speak }\end{array}$ & $\begin{array}{l}\text { language } \\
\text { you plat } \\
\text { to hise }\end{array}$ & $\begin{array}{c}\text { knowledge } \\
\text { of the } \\
\text { target } \\
\text { culture }\end{array}$ & $\begin{array}{c}\text { the causc of } \\
\text { your } \\
\text { problems }\end{array}$ \\
\hline $\begin{array}{l}\text { Finglish- } \\
\text { speaking } \\
\text { counlities }\end{array}$ & $\begin{array}{l}\text { Г. } 20 \\
03\end{array}$ & $\begin{array}{ll}\Gamma & 21 \\
0 & 2\end{array}$ & $\begin{array}{ll}\text { none } & 3 \\
\text { a litile } & 8 \\
\text { some } & 10 \\
\text { enoutgh } & 2\end{array}$ & $\begin{array}{l}\text { Ianguage } 13 \\
\text { Culture } 9\end{array}$ \\
\hline $\begin{array}{c}\text { neighboring } \\
\text { countries }\end{array}$ & $\begin{array}{l}\mathrm{L} 22 \\
\Gamma: 10 \\
0.3\end{array}$ & $\begin{array}{l}\text { L } 2 \mathrm{~L} \\
\text { T } 3 \\
\text { O } 3\end{array}$ & $\begin{array}{lc}\text { none } & 1 \\
\text { a little } & 11 \\
\text { some } & 10 \\
\text { enough } & 4\end{array}$ & $\begin{array}{l}\text { Language } 18 \\
\text { Culture } 9\end{array}$ \\
\hline $\begin{array}{c}\text { non } \\
\text { neighboring } \\
\text { countries }\end{array}$ & $\begin{array}{l}\text { I. } 3 \\
\mathrm{~F}, 24 \\
08\end{array}$ & $\begin{array}{l}\text { I. } 3 \\
\text { F: } 24 \\
09\end{array}$ & $\begin{array}{lc}\text { nonc } & 5 \\
\text { a little } & 14 \\
\text { some } & 11 \\
\text { cnough } & 2\end{array}$ & $\begin{array}{l}\text { Language } 26 \\
\text { Cullune } 9\end{array}$ \\
\hline
\end{tabular}

L. locad lariguage

E- English

O-other communication tools

the countries they were traveling to. If we exclude the travelers to

Japan and China which have close historical tics to Korca and where many Korcan emigrants are living, the dominant use of English in traveling abroad becomes more evident. In this light, the survey clearly indicates the importance of teaching non English speaking countries' culture in English classrooms. This study is not intended to underestimate the importance of tcaching English spcaking countrics' culturc, but to emphasize the fact that we need to have a balanced view of forcign cultures. Once English is widely used for communication not only between the native and non native speakers but also between anybodics whose linguistic background is different from their communication partners'. the teaching of non English speaking coun tries' cultures has a legitimate place in 
English classrooms.

\section{Culture Education in Korean English Classrooms}

The Ministry of Education (1997) started to be aware of the importance of English as an international language and clcarly stated the goal of English education as follows:

The ultimate goal of learning English is contributing to the creation of unique Korean culture by accommodating global culture through the global language, English. However, if we consider it from a wider perspective, the goal is in understanding the global community members through commu nication and contributing to the world peace with friendship rather than our own national interests (p. 13).

Nlthough the importance of a balanced view of culture education in English classrooms is evident in many ways, the integration of the vicw to the curriculum and actual teaching practices are in doubt. This study explores how this view of culture education is realized in actual teaching practices by looking some English textbooks used in high school.

Language and culture are inscparable, so culture should be presented in forcign language textbooks in a manner to develop students' communicative competence and help them function properly in a given commu nicative situation. This study explores the way how culture is integrated in English textbooks by looking at five high school English textbooks. According to their content, reading materials and dialogs are classificd into English spcaking countries' culture,
Korcan culture, non English spcaking coun tries' culture, and culture frec content. For example, stories from English speaking countrics and explanations of English speaking culture is categorized as repre senting English speaking countries' cultures in the study. Culture frec content cannot be seen as representing any particular culture. Topics dealing with science, environment, personal story and others can fall in this category.

Out of 70 reading texts in five high school English textbooks, 30 matcrials represents English speaking countrics' culture, which are the most in number. The next comes the culture free content, which are mostly about science, environmental problems, and contrived stories by the authors. The text introducing Korcan culture is presented ten times, which include the topies of the general introduction of the country, Korcan history and other Korea related contents. Non English speaking countries' culture is presented nine times. However, many cases do not secm to give students information which is helpful for them to understand the culture and use the information for communicating with those from the culture. For example, the biography of Van Gogh is catcgorized as representing non English spcaking countries' culture, because he was a Netherlander. However. the introduction of his career as a painter is very doubtful in giving students any information about Netherland culture. If we exclude this kind of reading texts, there are few reading texts which helps students understand forcign culture other than English spcaking countries' culture.

Since dialogues in the textbooks mainly 
focus on teaching basic expressions necessary to communicate with forcigners in spolken language and their length is limited, their content is mostly culture free. Out of 106 dialogues present in the textbooks, 88 are classificd as representing the culture free content. Ten dialogues are introducing English speaking countries' culture, but the explanation is usually very bricf, presented in only a few words. Korcan culture is presented six times and non English speaking countries' culture is introduced only two times. Since it seems practically difficult to include cultural content in the dialogues which have only a few lines and their main purpose seems to lic in teaching oral expressions, we focus on the reading texts which have more room to accommodate cultural content. The number of cach cultural content in the reading texts is shown in Table 2.

Table 2. Frequency of Cultural Content Type

\begin{tabular}{|c|c|c|c|}
\hline & English & Korcan & Ton-English \\
\hline $\begin{array}{c}\text { historical } \\
\text { figure }\end{array}$ & 4 & 1 & 3 \\
\hline $\begin{array}{c}\text { general } \\
\text { culture }\end{array}$ & 3 & 5 & 1 \\
\hline $\begin{array}{c}\text { spccific } \\
\text { culture }\end{array}$ & 15 & 1 & 2 \\
\hline history & 2 & 1 & 3 \\
\hline literature & 4 & 5 & \\
\hline anccdote & 5 & \\
\hline
\end{tabular}

According to their content, reading texts present in five Korean high school English textbooks were catcgorized into a historical figure, general culture, a specific aspect of culture, history, literature, and an ancedotc. $\Lambda$ historical figures refers to the bricf biography of a distinctive person from a specific culture. General culture refers to the attempt to define a wide range of culture in the text. Specific culture refers to a specific aspect of culture which mostly focuses on helping students behave properly in communicating with forcigners. Literature refers to a literary work written by a writer from a specific culture. And an anecdote refers to a story which happened in a specific culture.

In the case of the presentation of English culture, the introduction of the specific culture is the most in number. This is probably because the authors of the textbooks may think that this type of cultural knowledge may help students build socio linguistic competence and communicate adequately with those from the target culture. However, the pitfall of this assumption may be that any single rule cannot cover every occasion of a particular communication situation. Rather, it is suggested that the underlying rules applicable to a wide spectrum of commu nication situations be presented as well as that students be given opportunities to think over what may or may not be appropriate in the situations. Another point to notice is the attempts to generalize culture in short texts. The generalization of culture is not only practically infeasible, but leads to the danger of overgeneralizing or stereotyping. The brief explanation of the history may lead to the same pitfall.

Unlike the previously discussed three types of cultural content, the inclusion of literature, historical figures, and ancedote from the target culture secms more desired in that it should give students more room to interpret cultural phenomena from their own perspective. For example, when students read 
an anecdote, they are given opportunities to think over the underlying rules which operates in a specific situation to make a sense out of it. However, caution is required in that it should be drawn from authentic resources. Likewise, literature and historical figures give students to reflect cultural meanings included in them and touch the underlying culture which helps people understand the bchaviors of a cultural group. Lalande II (1988) and Purcell (1988) also reported the positive effect of the integration of literature in cultural study. However, this type of reading texts should not only include accurate information, but carry cultural meanings.

In the case of presenting Korean culture in the textbooks, the most noticcable phenomena was the attempts to generalize the wide spectrum of Korean culture in short texts. Again, this kind of presenting culture can lead to a danger to overgeneralize or stercotype culture, failing to touch its decp side. In addition, this way of presenting culture is not appropriate to help students identify their own culture as well as discover the differences and similarities between their own and the target culture. They are more likely to present what students have already known and give rare opportunities to reflect the underlying principles which operates in their bchaviors. Further, the presentation of history does not seem much helpful to gain cultural insights which are necessary to understand own cultural identity.

Non English spcaking countries' culture is introduced nine times. This negligence of non English speaking countries' culture may lead to the vicw that English is only for communicating with those from English speaking countries rather than for international communication. In terms of its content, three historical figures from non English speaking countries cultures are introduced in the textbooks. The life of Van Gogh as a painter is presented twice and Nexander, the Great as a conqueror is presented once. However, this way of describing historical figures focuses only on an individual, not the culture which they were a member of. In contrast, choosing such a figure as Mark Twain seems more desired in that he was a great contributor to shaping American culture, helping students understand American culture by exploring his life. Further, literary works by foreign writers from non English speaking countries are presented three times. $\Lambda$ s previously discussed, this way of introducing culture seems desired, but caution is necessary to include the works which are rich in cultural meanings. Two cases of introducing history are included in the textbooks. One of them is about Vikings. It is very helpful for students to understand Scandinavian people and culture in that the history of Vikings is really at the center of the culture and people's lives.

Further, one of the textbooks includes a special page for presenting culture in each lesson. Out of 11 lessons, English spcaking culture is introduced four times, non English speaking forcign culture five times, and culture free content five times. In terms of the number of presenting non English spcaking countries' culture, the textbook moves in the right direction. However, the problem lies in the way of presenting culture. Again, culture should be presented in a way that asks students to think over it as well as 
help them understand the underlying principles which operate in its member's cultural behaviors. Otherwise, it is likely to lead the overgeneralization and stereotyping of culture. In this light, the New Interchange series written by Jack C. Richards, Jonathan Hull, and Susan Proctor (1997) is worth noting. The series frequently uses statistics and fact sheets. This way of presenting culture gives students opportunities to think over a specific culture and is more likely to show the balanced and overall picture of the culture.

Overall, the textbook authors need to use great caution in selecting the content of the books. Language and culture are inseparable. So if we want to develop students' communicative competence, cultural content should be eagerly integrated into the textbooks. Reading texts and other language practices should not be intended to develop their language skills only, but their overall communicative competence. Culture-free content needs to be avoided as much as possible in this sense. Another point is the more active integration of non-Englishspeaking countries' cultures in the textbook. English has become a language for international communication, not only for communicating with the native speakers. Therefore, there should be the authors' special consideration of integrating the cultures in the textbooks in terms of the volume and manner of presenting the culture.

\section{Summary and Discussion}

This study begins with the attempt to define the concept of culture. It points out that the concept is very difficult to define in a clear manner. Instead, it is suggested that we have the better understanding of the concept by examining its multi-faced nature and various elements concerned. Then, we explore the role of culture in the context of foreign language learning. Cultural knowledge is of critical importance in communicating with those whose native culture is different from ours, so the proper understanding of the target is required to adequately function in a given communication situation. In this light, it is indicated that, instead of presenting the surface culture, students should be given opportunities to experience the deep culture. In addition, this study advises that culture education should be practiced after the consideration of students' level of cultural awareness as well as in a progressive manner.

In the next part of the study, the results of the two studies are discussed. The first study is about Koreans' language use in foreign countries. Except for those who were traveling to the neighboring countries such as Japan and China, the majority of the respondents to the survey relied on English as a major communication tools in foreign countries. This result clearly indicates the importance of the integration of foreign culture other than English-speaking countries' culture into the English curriculum. The second study is the analysis of five Korean English textbooks in terms of the presentation of culture. English-speaking countries' culture is the most frequently presented, followed by culture-free content, Korean culture, and non-English-speaking countries culture in order. The study also points out the problem of few presentation of the non-English-speaking countries' culture 
as well as that of presenting the surface culture in many cases.

Pedagogically, this study brings threc important issues to English curriculum. The first issue is the more active integration of non English speaking countries' culture into English curriculum. The rationale for this argument is that not only is English the most dominant language for international communication, but the understanding of forcign culture enables students to function properly in the situation.

The second point is the introduction of the decp culture which underlies a person's bchaviors in a cultural group. The presentation of the surface culture itself is not much helpful for students to reach a high level of cultural awareness. Further, when a person tries to communicate with those from different culture, the knowledge of the surface culture is far short of enabling them to facilitate the communication process. The understanding of the decp culture can be applied to the interpretation of a wide range of the surface culture.

And the last point is that the starting point of culture cducation should be the understanding of one's own culture. If students lack the proper understanding of their own culture, it is not possible to achicve the understanding of forcign culture. The understanding of onc's own culture helps students form the concept of culture, and the concept can be readily used for the understanding of forcign culture. $\Lambda$ s a matter of fact, onc's attempt to understand forcign culture without that of one's own culture is more like building a house on sand.

\section{References}

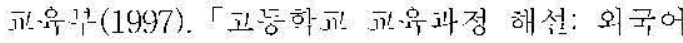
(영어)」. 서울: 대한 $\bar{t}$ 과서다식회사.

김졍운 - 박남식(1996). High school English for

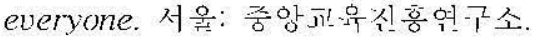

빈재식 · 김녕기 · 류기영 · T. Pattison· S. $\Lambda$. Stupak(1996). High school English for everyone. 서울: 시사영어사.

심명호 - 문용 - 권오량· R. C. Carter · 황종베 (1996). High school English for everyone. 서울: ㅍt학사.

장영희 · 김신절 - 홍명혜 · 김성절(1996). High school English I. 서울: 국산.

전상범 · 김임득 - 이병춘 - 긲기호 · 안성호 · 한문 섬(1996). High school English for everyone. 서울: 름성출한사.

Arries, J. F. (1994). Constructing culture study units: $\Lambda$ blucprint and practical tools. Foreign Language Annals, 27, 523531.

Cortazzi, M., \& Jin, L. (1999). Cultural mirrors: Materials and methods in the EFL classroom. In E. Hinkel (Ed.), Culture in second language teaching and learning (28 16). Cambridge, LK: Cambridge University Press.

Crystal, D. (1997). English as a global language. Cambridgc, UK: Cambridgc University Press.

Flewlling, J. L. (1994). The teaching of culture: Guidelines from the National Core French Study of Canada. Foreign Language Annals, 27, 133 111.

Graddol, D. (1997). The future of English? London: British Council.

Groctz, C. (1973). The interpretation of cultures. Now York: Basic Books.

Hammers, J. (1985). Culture and language: The individual approach. Foreign 
Language Annals, $18,5358$.

Heusinkveld, P. R. (1985). The forcign language classroom: $\Lambda$ forum for understanding cultural stereotypes. Foreign Language Annals, 18, 321325.

Jourdain, S. (1998). Building connections to culture: $\Lambda$ student centered approach. Foreign Language Annals, 31, 139150.

Kluckhohn, F., \& Strodtbeck, F. (1961). Variations in value orientations. Evanston, IL: Row, Peterson, \& Co.

Kramsch, C. (1998). The privilege of the intcrcultural spcaker. In M. Byram and M. Floming (Eds.), Language learning in intercultural perspective (16 31). Cambridge, LK: Cambridge University Press.

Krocber, A. L., \& Kluckhohn, C. (1951). Culture: $\Lambda$ critical review of concepts and definitions. New York: Random House.

Lalande II, J. F. (1988). Teaching literature and culture in the high school language class. Foreign Language Annals, 21, 573581.

Lantolf, J. P. (1999). Second culture acquisition: Cognitive considerations. In E. Hinkel (Ed.), Culture in second language teaching and learning (28 16). Cambridgc, LK: Cambridge University Press.

LcBlanc, R. (1990). A synthesis, National Core French Study. Ottawa: Association Canadienne des Professeurs de Langues Secondes, M Editeur.

Mantle Bromley, C. (1992). Preparing students for mcaningful culture lcarning. Foreign Language Annals, 25, 117127.

Mantle Bromlcy, C. (1993). Preparing teachers to make a difference in global cducation. Foreign Language Annals, 26, 208216.

Moran, P. R. (2001). Teaching culture:
Perspectives in practice. Boston: Hcinle \& Heinle.

Purcell, J. M. (1988). Cultural appreciation through litcrature. Foreign Language Annals, 21, 1921.

Richards, J. C., Hull, J., \& Proctor, S. (1997). New interchange: English for international communication. Cambridge, UK: Cambridge University Press.

Robinson, G. L. (1988). Crosscultural understanding. New York: Prentice Hall.

Rosenbusch, M. H. (1992). Is knowledge of cultural diversity enough? Global cducation in the clementary school forcign language program. Foreign Language Annals, 25, 129136 .

Ryan, P. M. (1996). Sociolinguistic goals for forcign language tcaching and teachors' metaphorical images of culture. Foreign Language Annals, 29, 571586.

Sccyle, H. N. (1981). Teaching culture: Strategies for intercultural communication. Lincolnwood, IL: National Textbook Company. 


\section{$\Lambda$ ppendix}

\section{Survey of Language Use in Foreign Countries}

1. Where is your destination?

2. What foreign language can you speak?

3. What language are you expected to speak in your visiting country?

1. How much cultural knowledge of the visiting country do you have?
1) none
2) a little
3) some but not enough
1) cnough to travel without difficulty

5. What is the most difficult thing when you travel abroad?

1) limited language ability

2) lack of cultural knowledge of the visiting country 


\title{
초록
}

\section{영어교육에 있어서 새로운 문화교육 방향의 제시}

\author{
류 호 열
}

(한경대학교)

언어와 문화는 불가분의 관계인 것처럼 외국 어 교육에서의 학생들의 의사소통 능력의 발달 을 위한 외국 문화의 소개는 너무도 당연하다 고 하겠다. 교통, 통신 수단의 밝달에 따라 영 어가 영어를 모국어로 사용하는 원어핀과의 의 사소통만을 위한 언어가 아니라 모국어가 같지 않은 외국인끼리의 의사소통을 위한 국제어가 됨에 따라 우리와 접촉이 잦은 외국인들의 문 화를 영어 교과서에 소개할 필요성을 본 연구 는 제기하고 있다. 이러한 추장을 뒷받침하기 위하여 본 연구에서는 외국 여행객들의 행선지 및 행선지에서의 언어 사용에 대한 간단한 조 사를 실시하였다. 조사 결과 비영어권 국가로 여행을 하는 많은 여행객들이 사용가능한 외국 어는 영어 하나이며 여행지에서 주된 언어로 영어를 사용할 계획이라고 응답하였다. 이러한 조사 결과는 비 영어권 국가들의 문화가 적극 적으로 영어교과서에 소개되어야 된다는 당위 성을 나타내고 있다하겠다. 또한 문화에 대한
교육이 실제 영어교육에 어떻게 반영되고 있는 지를 조사하기 위하여 실시된 고등학표 공통영 어 5종에 대한 조사는 문화에 대한 교육이 바 람직한 형태로 시행되고 있시 않음을 확인시켜 주었다. 즉 교과서에서 문화적인 내용을 다룰 수 있는 읽기 지문에서 영어뤈 문화 및 문화적 인 요소가 걸여된 내용이 대다수를 차지하고 있었으며 또한 학생들의 문화적인 이해를 돕기 보다는 문화의 포면적인 내용만을 다루고 있는 경우가 많았다. 이러한 문제를 해걸하기 위하여 본 연구는 문화의 표면적인 내용보다는 문화의 심층적인 내용을 다루어 학생들의 문화에 대한 이해의 정도를 높일 필요가 있으며, 우리 문화 에 대한 학생들의 이해를 제고하여 외국 문화 의 이해에 대한 기초를 마련할 필요가 있으며, 국제어로서의 영어의 역할을 이해하여 비 영어 권 문화를 보다 적극적으로 그리고 올바른 방 향으로 영어교과서에 소개할 필요성을 제기하 였다.

Key Words : 영어교육, 문화교육, 국제어로서의 영어, 영어교재 개발 